\title{
Effects of ionizing radiation on the viability and proliferative behavior of the human glioblastoma T98G cell line
}

\author{
Hossam Murad ${ }^{1 *}$, Yaman Alghamian², Abdulmunim Aljapawe ${ }^{1}$ and Ammar Madania ${ }^{3}$
}

\begin{abstract}
Objective: Radiotherapy is the traditional therapy for glioma patients. Glioma has poor response to ionizing radiation (IR). Studying radiation-induced cell death can help in understanding the cellular mechanisms underlying its radioresistance. T98 G cell line was irradiated with $\mathrm{CO}^{60}$ source by 2 or $10 \mathrm{~Gy}$. MTT assay was used to calculate the surviving fraction. Cell viability, cell cycle distribution and apoptosis assays were conducted by flow cytometry for irradiated and control cells for the 10 Gy dose.

Results: The SF2 value for irradiated cells was 0.8. Cell viability was decreased from 93.29 to $73.61 \%$, while, the Sub G0/G1 phase fraction was significantly increased at $10 \mathrm{~Gy}$ after $48 \mathrm{~h}$. On the other hand, there was an increase in the percentage of apoptotic cells which reached $40.16 \%$ after $72 \mathrm{~h}$ at the same dose, while, it did not exceeds $2 \%$ for nonirradiated cells. Our results showed that, the T98G cells is radioresistant to IR up to $10 \mathrm{~Gy}$. Effects of irradiation on the viability of T98G cells were relatively mild, since entering apoptosis was delayed for about 3 days after irradiation.
\end{abstract}

Keywords: Glioma, T98G cell line, lonizing radiation, Radioresistance, MTT, Flow cytometry, Apoptosis

\section{Introduction}

Glioblastomas are tumors affecting the central nervous system. They rank among the most common primary tumors worldwide [1]. Only a small percentage of patients live for 2 years after disease onset [2]. These tumors are traditionally treated by surgery, however, it is impossible to completely eradicate the tumor due to its penetrating nature with neighboring tissues [3]. Therefore, surgery is followed by radiation therapy (60 Gy total dose within 6 weeks), which increases the chance of recovery. In most cases, radiation resistant cancer cells settle in sensitive locations of the brain, which cannot be accessed by surgery, leading to relapse [4-6].

Several studies investigated cellular behavior after exposure to IR, the capacity of radiation to stop proliferation of cancer cells and to induce apoptosis [7-9]. IR

\footnotetext{
*Correspondence: ascientific@aec.org.sy

${ }^{1}$ Human Genetics Division, Department of Molecular Biology \& Biotechnology, Atomic Energy Commission of Syria (AECS), P.O. Box 6091, Damascus, Syria

Full list of author information is available at the end of the article
}

induces DNA damage, this damage can influence cell fate [10,11]. After DNA damage occurs, DNA damage pathways are activated, leading to cell cycle arrest, DNA damage repair, cell proliferation, senescence, or apoptosis $[11,12]$. Exposure to IR causes failure in cell division and loss of some genetic material, showing an aberrant distribution of chromosomes during division [13]. Previous studies showed that, preferential activation of the DNA damage checkpoint and enhanced DNA repair capacity in gliomas lead to radioresistance $[9,14,15]$. Strategies depending on targeting DNA damage response network in gliomas were applied to sensitize tumors and reverse radioresistance [16, 17]. Furthermore, another studies showed abrogating the cell cycle checkpoint could increase radiosensitivity in glioma cell line $[17,18]$.

Several studies showed that IR causes glioma cells to enter apoptosis [19, 20]. Apoptosis is an active mechanism of cell death, requiring the activation of a cascade of caspases genes, leading to DNA fragmentation and plasma membrane disintegration [21]. It has been shown that the extent of this process determines cells sensitivity to IR [13]. Some studies have shown that radiation did 
not cause apoptosis in the U343 cell line derived from glioblastoma multiforms, which makes it radioresistant $[22,23]$. Full understanding of the glioblastomas response to IR and detailed radioresistance analysis may help to identify radiosensitizing agents of this fatal disease.

Several methods have been developed to measure cell sensitivity to radiation, such as the MTT spectrophotometric assay [24, 25]. The SF2 value (surviving fraction at 2 Gy) is used as an indicator for cell sensitivity to radiation. Cells are considered radioresistant if the SF2 value exceeds 0.5 and radiosensitive if the SF2 value is less than $0.5[26,27]$.

Flow cytometry has been used to determine cell viability and rate of cell death caused by radiation in cell lines derived from glioblastomas $[28,29]$. Flow cytometry can also be used to study cell proliferation and cell cycle distribution utilizing cellular DNA content histograms. Annexin- $\mathrm{V}$ assay is a quantitative method that can be used to detect and quantify cells entering apoptosis [30, 31].

The aim of this study was to estimate the sensitivity of the T98G cells (as a model of glioblastomas) to IR and to investigate the effects of a high dose of IR on the T98G cell lines at the cellular levels, by studying the cell viability, cell cycle and apoptosis to investigate the behavior of this cells to this dose.

\section{Main text}

\section{Materials and methods}

\section{Cell culture}

T98G cells were kindly provided by Prof. Dr. P. Bécuwe, University of Nancy. Sub cultures of this cell line were maintained in complete RPMI-1640 medium containing $10 \%$ FBS (fetal bovine serum), $2 \mathrm{mM}$ glutamine, $0.1 \mathrm{mg} /$ $\mathrm{ml}$ each of penicillin and streptomycin, at $37^{\circ} \mathrm{C}$ and $5 \%$ $\mathrm{CO}_{2}$. All cell culture media were purchased from (Gibco, USA).

\section{Cells irradiation}

Cultures of T98G cells were irradiated in the irradiation reference laboratory at (AECS) using a $\mathrm{Co}^{60}$ source (Theratron 80, USA), Doses used were 2 or 10 Gy and the dose rate was of $447 \mathrm{mGy} / \mathrm{min}$.

\section{MTT spectrophotometric assay}

The MTT kit (Roche, Germany) was used as previously reported [32] to measure T98G cells sensitivity to radiation. Cells were cultured in 96-well plates (5000 cells/ well) and irradiated with the 2 Gy. The value of SF2, which reflects the sensitivity of the cells to radiation, was calculated using the following equation: $\mathrm{SF}=2-(\mathrm{t}$ delay/t doubling time), where: " $t$ delay" is the time needed for irradiated cells to reach an absorbance equal to that of control cells, "t doubling time" is the time cells need to double their number.

\section{Cell cycle analysis}

T98G cells were treated with a 10 Gy of IR and returned to the incubator for 6, 24, 48 and $72 \mathrm{~h}$. Cells were collected, washed with PBS and stained for cell cycle analysis using BD Biosciences cell cycle test kit (BD Biosciences, USA). For each sample, $1 \times 10^{4}$ cells were analyzed using the BD FACSCalibur flow cytometer (Becton-Dickinson, USA).

\section{Cell viability assay}

T98G cells were irradiated with the $10 \mathrm{~Gy}$, then, harvested after 6, 24, 48 and $72 \mathrm{~h}$. Cells then washed with PBS buffer and stained for cell viability using BD Biosciences viability kit.

\section{Apoptosis assay}

10 Gy irradiated T98G cells were collected after 6, 24, 48 and $72 \mathrm{~h}$ of irradiation. Cells then washed with PBS buffer and stained using BD Biosciences Apoptosis Detection Kit I.

\section{Statistical analysis}

The SPSS 23 software (SPSS, Chicago) was used in statistical analysis. The Student- $t$ test was applied to analyze the differences between treatments. Differences were considered statistically significant at " $\mathrm{P}<0.05$.

\section{Results \\ Radiosensitivity and viability of T98G cells}

The SF2 value for cells irradiated with 2 Gy was 0.8 , which is clearly greater than 0.5 , indicating that the T98G cells are radioresistant. As shown in (Fig. 1), growth of irradiated cells was delayed about $12 \mathrm{~h}$ compared to nonirradiated cells. Viability of T98G cells exposed to a $10 \mathrm{~Gy}$ was dropped to $93.29,91.62$ and $73.61 \%$ after 6,24 and $48 \mathrm{~h}$ respectively, (Fig. 2a).

\section{Effect of IR on the cell cycle of T98G cells}

As shown in Fig. 2b, the percentage of dead cells increased to $3.53,3.43,7.93$ and $13.3 \%$ after $6,24,48$ and $72 \mathrm{~h}$ of irradiation respectively. We found that the percentage of cells found in G1 phase was decreased after 6 , 24,48 and $72 \mathrm{~h}$ to $73.64,63.29,49.52$ and $46.97 \%$ respectively, after irradiation with $10 \mathrm{~Gy}$. While the percentage of 10 Gy irradiated cells found in G2 phase was 9.22, $22.11,26.33$ and $22.66 \%$ after $6,24,48$ and $72 \mathrm{~h}$ respectively showing a slight $\mathrm{G} 2 / \mathrm{M}$ cell cycle arrest. 


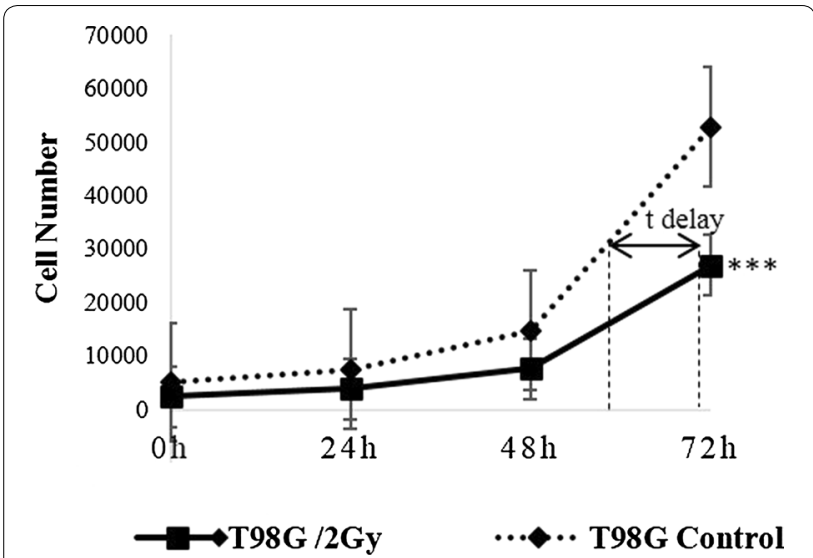

Fig. 1 Determination of the radiosensitivity of the T98G cell line using the MTT method. Absorbance values were converted to cells number using a logarithmic line equation of a stander curve for each point, $Y$ axis: cell number, $X$ axis: time. Irradiation of T98G cells with a 2 Gy dose caused a growth delay of about $12 \mathrm{~h}$ compared to non-irradiated cells (control). The experiment has been repeated three times and data are expressed as the mean \pm SD

\section{Effect of IR on apoptosis of T98G cell line}

We used the double staining method (annexin V-FITC and IP) and flow cytometry to determine the percentage quadrant). Flow cytometric analysis demonstrated that after irradiation with $10 \mathrm{~Gy}$, apoptosis rate (sum of the R1 and R3 quadrants) increased from 9.63 to $20.88 \%$ and to $40.16 \%$ after 24,48 and $72 \mathrm{~h}$ respectively.

\section{Discussion}

Glioblastomas represent one of the deadliest cancer types, where affected patients generally die within 2 years after disease onset [33]. In spite of the high radioresistance of glioblastoma cells, IR remains one of the traditional therapies for those tumors [34, 35]. Radioresistance of cancer cells was the subject of numerous studies, due to its importance in cancer therapy practice and implications in several molecular pathways, such as DNA repair, cell cycle check points and cell death [14, 36, 37]. The high resistance of glioblastoma cells to radiotherapy is attributed to weak entrance into programmed cell death induced by IR [38]. Ionizing radiation induces damage to the genetic material of the cell, negatively affecting several vital cellular mechanisms [14]. As a response to these damages, cells can select one of several possible pathways according to the nature, intensity and duration of the induced effect (chemotherapy, radiotherapy, pharmacological drugs, etc.) [11, 12]. Cells can continue their division, ignoring the induced effect, or their cell cycle arrest

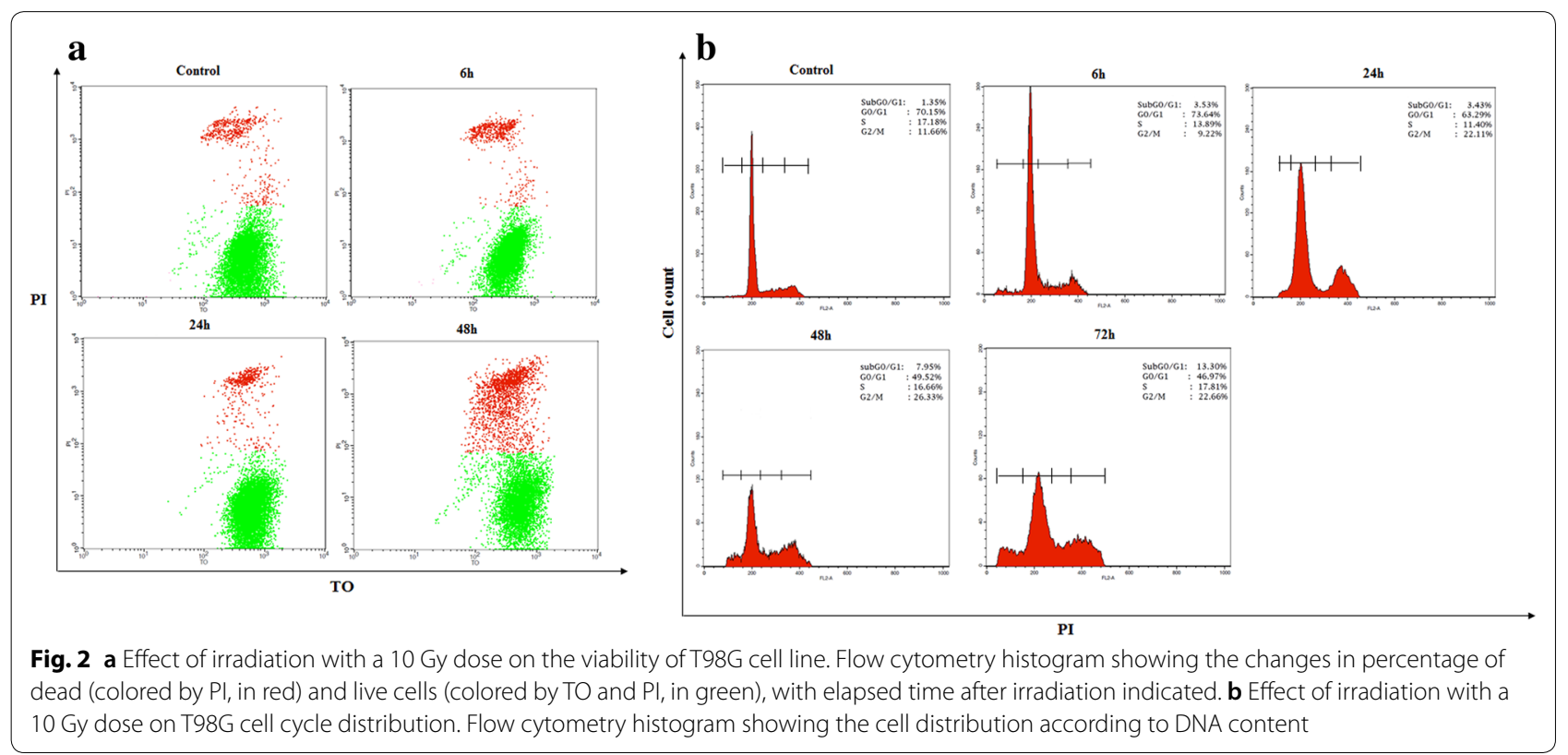

of cells undergoing programmed cell death due to irradiation. As shown in Fig. 3, we distinguished four groups of cells: live (annexin $\mathrm{V}^{-} \mathrm{PI}^{-}, \mathrm{R} 2$ quadrant), early apoptotic (annexin $\mathrm{V}^{+} \mathrm{PI}^{-}, \mathrm{R} 3$ quadrant), late apoptotic (annexinV ${ }^{+}$ $\mathrm{PI}^{+}, \mathrm{R} 1$ quadrant) and necrotic (annexin $\mathrm{V}^{-} \mathrm{PI}^{+}, \mathrm{R} 4$ until damages are repaired, then enter into senescence, differentiate, or enter into apoptosis if the damages are irreparable [3]. Furthermore, the fate of the tumor cell after radiotherapy is determined by its characteristics, such as type and tissue of origin [39]. The SF2 value is considered as an indicator for cells radiosensitivity [26, 


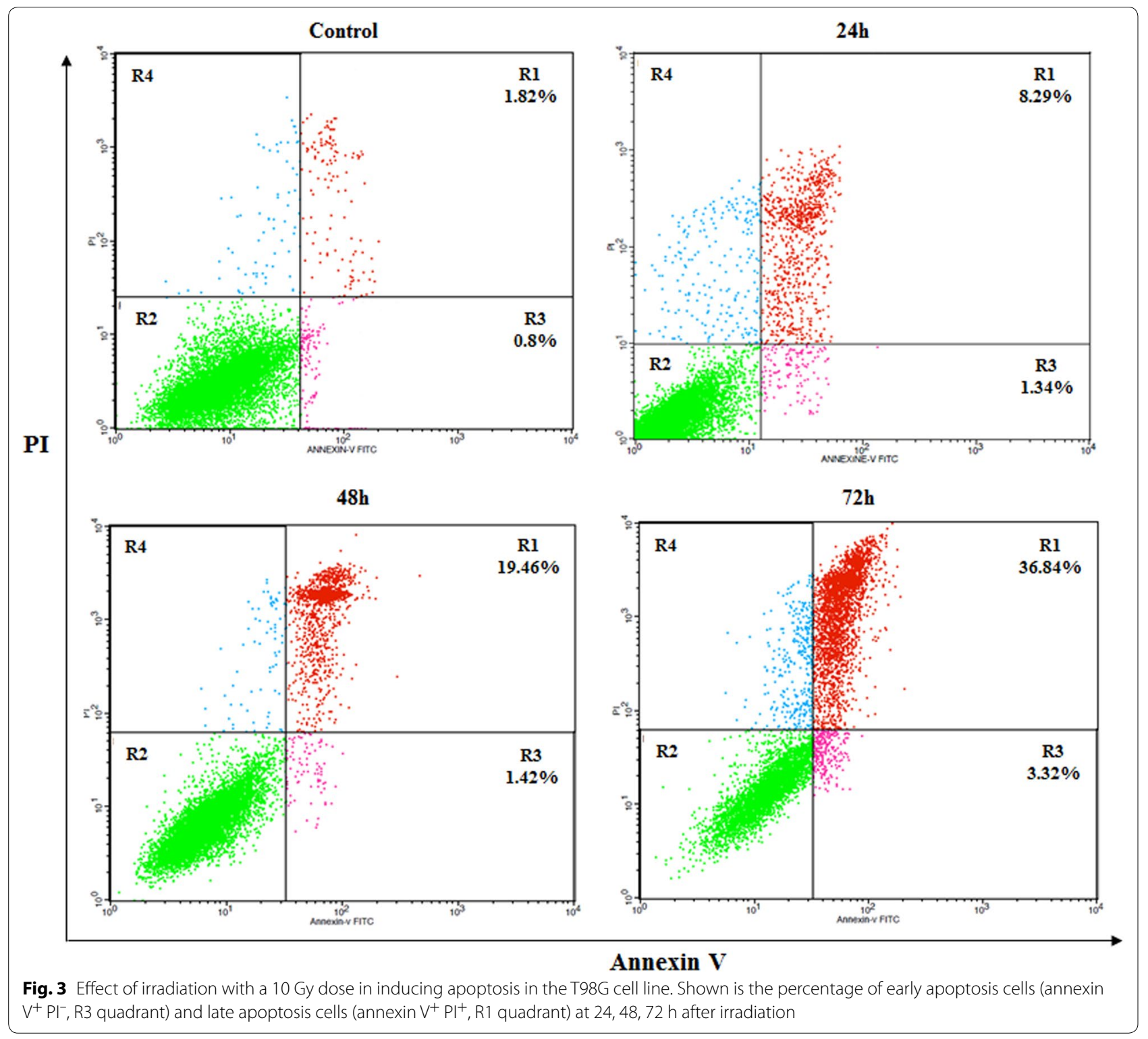

27]. Our results showed that, SF2 value was 0.8 , so the T98G cells were considered as radioresistant (Fig. 1). Previous study by Liu et al. showed that, T98G cells had SF2 value reach to 0.7 compared to other human cell lines [40]. In our study, the viability of irradiated cells (up to $10 \mathrm{~Gy}$ ) was slightly decreased after $48 \mathrm{~h}$ (Fig. 2a). Furthermore, exposing T98G cells to a $10 \mathrm{~Gy}$, (which is considered relatively a high dose), induced a significant cell death only after $72 \mathrm{~h}$ (Fig. 2b). Roy et al. showed that, the sensitivity of the tow U118 and U87 cells (glioblastoma cell lines) to IR at 6 Gy was more than ( $>2$-fold) compared to T98G cells [41]. Another study by Yao et al. revealed that, there was a significant inhibition of cell proliferation at 20 Gy for (GB-1, T98G, U251-MG, and
U373-MG) cells at $24 \mathrm{~h}$, and the apoptosis did not occur in any these cells following irradiation [38]. Our results showed, no accumulation of irradiated T98G cells in the SubG0/G1 phase after a $10 \mathrm{~Gy}$ at 6,24 and $48 \mathrm{~h}$, whereas, we observed a limited cell death at $72 \mathrm{~h}$. Yao et al. did not observe any dead T98G cells irradiated at $5 \mathrm{~Gy}$ in the SubG0 phase after 4 days [38]. Our results showed that, a 10 Gy irradiation resulted in a G2/M cell cycle arrest. This phase gives the cells an opportunity to repair damaged DNA induced by irradiation. However, when DNA damage is irreparable cells undergo apoptosis $[9,42,43]$.

In addition, double staining with annexin-V-FITC and PI showed that, the rate of apoptotic irradiated T98G cells reached $40.16 \%$ at $72 \mathrm{~h}$. Ma et al. pointed 
that, there was only $16 \%$ of death rate after $96 \mathrm{~h}$ for U251 MG cells (glioblastoma cells) irradiated at 7 Gy [9]. Several studies suggested a combination treatment for T98G cells to improve their radiosensitivity to IR. Tani et al. showed that, the continuous down-regulation of $\gamma$-glutamylcysteine synthetase $(\gamma$-GCS) expression by hammerhead ribozyme (as a potential anticancer gene therapy), increased the cytotoxicity of the T98G cells to IR [44]. Although, treatment of T98G cells with BI 2536 (as an inhibitor for Polo-like kinase 1) caused mitotic arrest and increased apoptosis in irradiated cells after $24 \mathrm{~h}[45]$.

\section{Conclusions}

Taken together, our results showed that even in the highdose, $10 \mathrm{~Gy}$, cells did not respond to ionizing radiation after $24 \mathrm{~h}$, while, these cells needed about $72 \mathrm{~h}$ to inter in apoptotic phase by a rate not exceeding $40 \%$ at the same dose. We conclude that, the ionizing radiotherapy alone even in a high dose, does not lead to the efficient treatment in advanced grade glioblastoma patients.

\section{Limitations}

Further studies are necessary in order to elucidate the molecular mechanisms causing cell resistance to IR, and to identify the genes responsible for radioresistance. These genes would be potential targets for targeted therapies that would improve response to IR and force cancer cells to enter cell death.

\section{Abbreviations \\ SF2: surviving fraction at 2 Gy; MTT: (3-(4,5-dimethylthiazolyl-2)-2,5-diphe- nyltetrazolium bromide); TO: thiazole orange; PI: propidium iodide.}

\section{Authors' contributions}

$H M, Y A$ and AA conceived the study, its design and coordination. AM drafted the manuscript. All authors read and approved the final manuscript.

\section{Author details \\ ${ }_{1}^{1}$ Human Genetics Division, Department of Molecular Biology \& Biotechnol- ogy, Atomic Energy Commission of Syria (AECS), P.O. Box 6091, Damascus, Syria. ${ }^{2}$ Department of Animal Biology, Faculty of Sciences, Damascus Uni- versity, Damascus, Syria. ${ }^{3}$ Department of Radiation Medicine, Atomic Energy Commission of Syria (AECS), Damascus, Syria.}

\section{Acknowledgements}

We would like to thank Prof. Ibrahim Othman, the Director General of AECS, and the Head of department of Molecular Biology \& Biotechnology and also, the head of department of Radiation Medicine for their support.

\section{Competing interests}

The authors declare that they have no competing interests.

\section{Availability of data and materials}

All data generated or analyzed during this study are included in this published article.
Consent for publication

Not applicable.

\section{Ethics approval and consent to participate}

This study has been approved by the Institutional Review Board of the Atomic Energy Commission of Syria (AECS).

\section{Funding}

This project was financially supported by Atomic Energy Commission of Syria (AECS).

\section{Publisher's Note}

Springer Nature remains neutral with regard to jurisdictional claims in published maps and institutional affiliations.

Received: 8 March 2018 Accepted: 11 May 2018

Published online: 21 May 2018

\section{References}

1. Wen PY. New developments in targeted molecular therapies for glioblastoma. Expert Rev Anticancer Ther. 2009;9:7-10

2. Houillier $\mathrm{C}$, Lejeune J, Benouaich-Amiel A, Laigle-Donadey F, Criniere $\mathrm{E}_{\text {, }}$ Mokhtari K, Thillet J, Delattre JY, Hoang-Xuan K, Sanson M. Prognostic impact of molecular markers in a series of 220 primary glioblastomas. Cancer. 2006:106:2218-23.

3. Jo GH, Bogler O, Chwae YJ, Yoo H, Lee SH, Park JB, Kim YJ, Kim JH, Gwak HS. Radiation-induced autophagy contributes to cell death and induces apoptosis partly in malignant glioma cells. Cancer Res Treat. 2015:47:221-41.

4. Maher EA, Furnari FB, Bachoo RM, Rowitch DH, Louis DN, Cavenee WK, DePinho RA. Malignant glioma: genetics and biology of a grave matter. Genes Dev. 2001;15:1311-33.

5. Sheline GE. Radiation therapy of brain tumors. Cancer. 1977;39:873-81.

6. Garden AS, Maor MH, Yung WK, Bruner JM, Woo SY, Moser RP, Lee YY. Outcome and patterns of failure following limited-volume irradiation for malignant astrocytomas. Radiother Oncol. 1991;20:99-110.

7. Puck TT, Marcus PI. Action of X-rays on mammalian cells. J Exp Med. 1956:103:653-66.

8. Little JB. Failla memorial lecture. Changing views of cellular radiosensitivity. Radiat Res. 1994:140:299-311.

9. Ma H, Rao L, Wang HL, Mao ZW, Lei RH, Yang ZY, Qing H, Deng YL. Transcriptome analysis of glioma cells for the dynamic response to gamma-irradiation and dual regulation of apoptosis genes: a new insight into radiotherapy for glioblastomas. Cell Death Dis. 2013:4:e895.

10. Jackson SP, Bartek J. The DNA-damage response in human biology and disease. Nature. 2009:461:1071-8.

11. Smith LE, Nagar S, Kim GJ, Morgan WF. Radiation-induced genomic instability: radiation quality and dose response. Health Phys. 2003:85:23-9.

12. McMillan TJ. Residual DNA damage: what is left over and how does this determine cell fate? Eur J Cancer. 1992;28:267-9.

13. Joshi GP, Nelson WJ, Revell SH, Shaw CA. X-ray-induced chromosome damage in live mammalian cells, and improved measurements of its effects on their colony-forming ability. Int J Radiat Biol Relat Stud Phys Chem Med. 1982;41:161-81.

14. Bao S, Wu Q, McLendon RE, Hao Y, Shi Q, Hjelmeland AB, Dewhirst MW, Bigner DD, Rich JN. Glioma stem cells promote radioresistance by preferential activation of the DNA damage response. Nature. 2006;444:756-60.

15. Otomo T, Hishii M, Arai H, Sato K, Sasai K. Microarray analysis of temporal gene responses to ionizing radiation in two glioblastoma cell lines: upregulation of DNA repair genes. J Radiat Res. 2004:45:53-60.

16. Lord CJ, Ashworth A. The DNA damage response and cancer therapy. Nature. 2012:481:287-94.

17. Russo AL, Kwon HC, Burgan WE, Carter D, Beam K, Weizheng X, Zhang J, Slusher BS, Chakravarti A, Tofilon PJ, Camphausen K. In vitro and in vivo radiosensitization of glioblastoma cells by the poly (ADP-ribose) polymerase inhibitor E7016. Clin Cancer Res. 2009:15:607-12.

18. Jin P, Gu Y, Morgan DO. Role of inhibitory CDC2 phosphorylation in radiation-induced G2 arrest in human cells. J Cell Biol. 1996:134:963-70. 
19. Afshar G, Jelluma N, Yang X, Basila D, Arvold ND, Karlsson A, Yount GL, Dansen TB, Koller E, Haas-Kogan DA. Radiation-induced caspase-8 mediates p53-independent apoptosis in glioma cells. Cancer Res. 2006;66:4223-32.

20. Hara S, Nakashima S, Kiyono T, Sawada M, Yoshimura S, Iwama T, Banno Y, Shinoda J, Sakai N. p53-independent ceramide formation in human glioma cells during gamma-radiation-induced apoptosis. Cell Death Differ. 2004;11:853-61.

21. Estus S, Zaks WJ, Freeman RS, Gruda M, Bravo R, Johnson EM Jr. Altered gene expression in neurons during programmed cell death: identification of c-jun as necessary for neuronal apoptosis. J Cell Biol. 1994;127:1717-27.

22. Hong $X$, Lei L, Glas R. Tumors acquire inhibitor of apoptosis protein (IAP)mediated apoptosis resistance through altered specificity of cytosolic proteolysis. J Exp Med. 2003;197:1731-43.

23. Bassi C, Mello SS, Cardoso RS, Godoy PD, Fachin AL, Junta CM, SandrinGarcia P, Carlotti CG, Falcao RP, Donadi EA, et al. Transcriptional changes in U343 MG: a glioblastoma cell line exposed to ionizing radiation. Hum Exp Toxicol. 2008;27:919-29.

24. Hashemi SNB. MTT assay instead of the clonogenic assay in measuring the response of cells to ionizing radiation. J Radiobiol. 2014;1:3-82.

25. Nikzad S, Hashemi B, Hassan ZM, Mozdarani H. The cell survival of F10B16 melanoma and $4 \mathrm{~T} 1$ breast adenocarcinoma irradiated to gamma radiation using the MTT assay based on two different calculation methods. J Biomed Phys Eng. 2013;3:29-36.

26. Deacon J, Peckham MJ, Steel GG. The radioresponsiveness of human tumours and the initial slope of the cell survival curve. Radiother Oncol. 1984;2:317-23.

27. Bjork-Eriksson T, West C, Karlsson E, Mercke C. Tumor radiosensitivity (SF2) is a prognostic factor for local control in head and neck cancers. Int J Radiat Oncol Biol Phys. 2000;46:13-9.

28. Haas-Kogan DA, Dazin P, Hu L, Deen DF, Israel A. p53-independent apoptosis: a mechanism of radiation-induced cell death of glioblastoma cells. Cancer J Sci Am. 1996;2:114-21

29. Yount GL, Haas-Kogan DA, Vidair CA, Haas M, Dewey WC, Israel MA. Cell cycle synchrony unmasks the influence of p53 function on radiosensitivity of human glioblastoma cells. Cancer Res. 1996;56:500-6.

30. van Engeland M, Ramaekers FC, Schutte B, Reutelingsperger CP. A novel assay to measure loss of plasma membrane asymmetry during apoptosis of adherent cells in culture. Cytometry. 1996;24:131-9.

31. Fadok VA, Voelker DR, Campbell PA, Cohen JJ, Bratton DL, Henson PM. Exposure of phosphatidylserine on the surface of apoptotic lymphocytes triggers specific recognition and removal by macrophages. J Immunol. 1992;148:2207-16.
32. Buch $K$, Peters T, Nawroth T, Sanger M, Schmidberger H, Langguth P. Determination of cell survival after irradiation via clonogenic assay versus multiple MTT Assay-a comparative study. Radiat Oncol. 2012;7:1.

33. Reitman ZJ, Winkler F, Elia AEH. New directions in the treatment of glioblastoma. Semin Neurol. 2018;38:50-61.

34. Rivera M, Sukhdeo K, Yu J. lonizing radiation in glioblastoma initiating cells. Front Oncol. 2013;3:74.

35. Braganza MZ, Kitahara CM, de Gonzalez AB, Inskip PD, Johnson KJ, Rajaraman $P$. Ionizing radiation and the risk of brain and central nervous system tumors: a systematic review. Neuro Oncol. 2012;14:1316-24.

36. Shu HK, Kim MM, Chen P, Furman F, Julin CM, Israel MA. The intrinsic radioresistance of glioblastoma-derived cell lines is associated with a failure of p53 to induce p21(BAX) expression. Proc Natl Acad Sci USA. 1998:95:14453-8.

37. Lomonaco SL, Finniss S, Xiang C, Decarvalho A, Umansky F, Kalkanis SN, Mikkelsen T, Brodie $C$. The induction of autophagy by gamma-radiation contributes to the radioresistance of glioma stem cells. Int J Cancer. 2009:125:717-22.

38. Yao KC, Komata T, Kondo Y, Kanzawa T, Kondo S, Germano IM. Molecular response of human glioblastoma multiform cells to ionizing radiation: cell cycle arrest, modulation of the expression of cyclin-dependent kinase inhibitors, and autophagy. J Neurosurg. 2003;98:378-84.

39. Panganiban RA, Snow AL, Day RM. Mechanisms of radiation toxicity in transformed and non-transformed cells. Int J Mol Sci. 2013;14:15931-58.

40. Liu ZG, Chen HY, Cheng JJ, Chen ZP, Li XN, Xia YF. Relationship between methylation status of ERCC1 promoter and radiosensitivity in glioma cell lines. Cell Biol Int. 2009;33:1111-7.

41. Roy K, Wang L, Makrigiorgos GM, Price BD. Methylation of the ATM promoter in glioma cells alters ionizing radiation sensitivity. Biochem Biophys Res Commun. 2006;344:821-6.

42. Short SC, Martindale C, Bourne S, Brand G, Woodcock M, Johnston P. DNA repair after irradiation in glioma cells and normal human astrocytes. Neuro Oncol. 2007:9:404-11.

43. Landsverk KS, Patzke S, Rein ID, Stokke C, Lyng H, De Angelis PM, Stokke T. Three independent mechanisms for arrest in G2 after ionizing radiation. Cell Cycle. 2011;10:819-29.

44. Tani M, Goto S, Kamada K, Mori K, Urata Y, Ihara Y, Kijima H, Ueyama Y, Shibata S, Kondo T. Hammerhead ribozyme against $\gamma$-glutamylcysteine synthetase attenuates resistance to ionizing radiation and cisplatin in human T98G glioblastoma cells. Jpn J Cancer Res. 2002;93:716-22.

45. Pezuk JA, Brassesco MS, Morales AG, de Oliveira JC, de Oliveira HF, Scrideli CA, Tone LG. Inhibition of polo-like kinase 1 induces cell cycle arrest and sensitizes glioblastoma cells to ionizing radiation. Cancer Biother Radiopharm. 2013:28:516-22.
Ready to submit your research? Choose BMC and benefit from:

- fast, convenient online submission

- thorough peer review by experienced researchers in your field

- rapid publication on acceptance

- support for research data, including large and complex data types

- gold Open Access which fosters wider collaboration and increased citations

- maximum visibility for your research: over 100M website views per year

At BMC, research is always in progress.

Learn more biomedcentral.com/submissions 